DOI https://doi.org/10.30525/978-9934-588-81-5-1.16

\title{
ANALYSIS OF PREGNANCY AND DELIVERY COURSE, FETAL AND NEWBORN CONDITION IN WOMEN WITH MISCARRIAGE (RETROSPECTIVE ANALYSIS)
}

\author{
Hychka N. M. \\ $P h D$,
}

Associate Professor at the Department of Obstetrics and Gynecology № 3

Bogomolets National Medical University

Kovaliuk T. V.

$P h D$,

Associate Professor at the Department of Obstetrics and Gynecology № 3

Bogomolets National Medical University

Oleshko V. F.

$P h D$,

Assistant at the Department of Obstetrics and Gynecology № 3

Bogomolets National Medical University

Kalganova M. A.

6th year Student

Bogomolets National Medical University

Sereda K. I.

6th year Student

Bogomolets National Medical University

Kyiv, Ukraine

Introduction. The perinatal aspects of miscarriage, despite the success in its pathogenetic mechanisms exploration, continue to be one of the leading problems in modern obstetrics $[1,2,3]$. Issues of perinatal complications prediction and prevention require a clear understanding of the aspects which influence on the threatening spontaneous abortions and premature deliveries $[4,5,6]$. These pregnancy complications cause complex changes in the "mother - placenta - fetus" system and in most cases are implemented in placental dysfunction, which affects the formation of perinatal complications and consequences $[7,9,10]$.

Nowadays it is considered relevant to study the adverse causes of the ante-and intranatal period which affect the frequency of perinatal complications among premature delivered newborns. In this regard, there is a need 
to solve the problem of adequacy and expediency of treatment and rehabilitation measures that affect the proportion of perinatal complications in prematurity $[2,8,9]$.

The Purpose of Research. To study the frequency and causes which affect the main indicators of preterm pregnancy results in order to improve organizational measures aimed at perinatal and obstetric complications preventions and improvement of medical care for premature delivered newborns.

Materials and methods of research. In order to achieve the result, a retrospective clinical and statistical analysis of 1976 pregnancy and delivery case histories of women who were treated and delivered in the Kiev City Maternity Hospital No. 3 for 2015-2019 was conducted. For an in-depth study of the causes and consequences of preterm deliveries, we analyzed the results of 83 histomorphological studies of placentas after preterm deliveries.

The Results of Research. The rate of spontaneous pregnancy termination has been growing rapidly in recent years and according to our analysis is equal to $4.5-5.2 \%$, with no significant reduction in the rate of preterm deliveries and a tendency to increase the rate of perinatal mortality among premature newborns.

Miscarriage, as a pathological course of pregnancy, was observed in pregnants aged on average from 25 to 35 years with a pronounced tendency to increase among underage ones. It should be noted that according to our maternity hospital, the frequency of first-time births among young primiparous has increased and was $1.77-2.7 \%$ of cases. Noteworthy is the fact that the frequency of young primiparous under the age of 16 has increased in 5 times.

Only $101(5.1 \%)$ women had satisfactory social conditions with sufficient material facility. The vast majority - 1875 (94.9\%) classified themselves as low-income with high psycho-emotional stress.

Among women with preterm deliveries the frequency of antenatal clinic registration in late gestation terms prevailed. Untimely registration in antenatal clinic led to a number of complications that resulted in premature deliveries in almost 553 (28.0\%) of women.

There was registered a high percentage of concomitant extragenital pathology in the examined pregnant women: cardiovascular system $387(19.6 \%)$, urinary system - $312(15.8 \%)$, respiratory tract $646(32.7 \%)$. Pathologies of the hepatobiliary system, endocrine disorders, in particular obesity and diabetes in pregnant women with miscarriage ranged from $0.52 \%$ to $7.39 \%$. 
Complicated gynecological anamnesis in pregnant women with premature termination of pregnancy and preterm deliveries in the anamnesis ranged to $79.1 \%$ (1563 women). Analyzing the gynecological morbidity, it is necessary to note a high level of inflammatory diseases of the cervix $353(17.9 \%)$, menstrual disorders - $371(18.8 \%)$, background and precancerous diseases of the cervix - 284 (14.4\%), operations on the uterus $480(24.3 \%)$.

A high frequency of miscarriage was common to multigravidas, especially those who were going to have first deliveries $-1551(78.5 \%)$. The preterm pregnancy rate in primigravidas was $424(21.5 \%)(\mathrm{p}<0.05)$.

Complicated obstetric anamnesis was characterized by the presence of combined obstetric pathologies. Threatening spontaneous abortions at early terms were observed in $310(15.7 \%)$, and threatening preterm deliveries in $543(27.5 \%)$. The aggregate of habitual miscarriage was $13.46 \pm 0.84 \%$.

The leading factors of adverse influence on the condition of a premature delivered newborn are complications during the course of preterm deliveries. The frequency of premature amniotic membranes rupture was $42.1 \%$ (831 cases). Anomalies of labor activity were detected in 782 (39.6) women. It should be noted that preterm labors with fast and rapid labor activity were diagnosed in $320(16.2 \%)$ of cases, and weakness of labor activity in $442(22.4 \%)$ cases. Manual examination of the uterine walls after deliveries was performed in $556(28.4 \%)$ of cases. The rate of Caesarean sections for prematurity during the examined period was $4.66 \pm 0.17 \%$, which is significantly lower than in the General population of women. The main causes of Cesarean section in preterm deliveries were: premature detachment of the normally located placenta $-476(24.1 \%)$, acute fetal distress $407(20.6 \%)$, preeclampsia of moderate and severe degree $-339(17.2 \%)$. In $203(10.3 \%)$ of cases, the indication for Cesarean section was bleeding due to placenta previa, and $67(3.4 \%)$ cases were associated with such indications as pelvic presentation, uterine scarring, rhesus conflict, severe diabetes mellitus and loss of umbilical cord loops. The analysis showed that perinatal losses after surgery and during preterm natural deliveries did not differ significantly.

It is important to note that a high rate of perinatal mortality was observed in premature infants with a body weight of 1000-1499 $\mathrm{g}$ and was $366.4 \pm 18.4 \%$. Perinatal mortality of premature infants with a body weight of $1500-1999 \mathrm{~g}$ was $242 \pm 15.6 \%$. The perinatal mortality rate of fetuses with a body weight of 2000-2499 $\mathrm{g}$ was significantly lower and ranged up to $64.8 \pm 6.2 \%$ o $(\mathrm{p}<0.001)$. 
The analysis of early neonatal mortality indicators revealed a correlation between the frequency of gestational age and weight after deliveries. This index among preterm delivered infants with body weight of 1000$1499 \mathrm{~g}$ was $183.1 \pm 52.7 \%$, with body weight of $1500-1999 \mathrm{~g}$ $144.8 \pm 31.3 \%$, and with body weight of $2000-2499-33.4 \pm 4.9 \%$, $(\mathrm{p}<0.05)$. Analyzing the premature newborns causes of death, it should be noted, that the frequency of respiratory distress syndrome has significantly decreased in recent years in the presence of an increase in intracranial hemorrhages of hypoxic origin and congenital malformations. Among the complications of the early neonatal period the main complications were hypoxic-ischemic encephalopathy $-76.9 \pm 8.2 \%$, intraventricular hemorrhage $-50.3 \pm 4.7 \%$, and congenital hypotrophy $-43.1 \pm 5.7 \%$. Respiratory distress syndrome rate among premature newborns was $57.1 \%$. Signs of gestational immaturity were established in $53.5 \%$ of cases, intrauterine infection was diagnosed in $19.4 \%$ of cases, hemorrhagic syndrome $-5.61 \%$ and edematous syndrome $-4.1 \%$.

Morphological analysis of 83 placentas after preterm deliveries revealed the presents of fetal-maternal circulatory disorders in the form of dilation, vascular hyperemia and stromal villi edema in 31 (37.3\%) cases, single and diapedetic hemorrhages in $23(27.7 \%)$, thickening of the artery walls of large villi in 29 (34.9\%) cases, and small villi infarctions in $30(36.1 \%)$ cases. The indicator of terminal villi in the placenta during preterm deliveries was on average $30.2 \pm 1.6 \%$, with control values of $38.0 \pm 1.8 \%(\mathrm{p}<0.05)$. It is noteworthy that with a decrease in terminal villi percentage the total crosssectional area increase up to $163.3 \pm 7.4 \mathrm{~mm}^{2}$ (the control values $112.8 \pm 4.2 \mathrm{~mm}^{2}(\mathrm{p}<0.05)$, which may be associated with a compensatory adaptive reaction of the placenta, although the specific area.

Initially the number of nodes on the chorion villi varies within considerable limits. In some placentas, they were almost absent, and in others they could be found in almost a third of small-diameter villi. In all cases, the presence of synticial nodes is observed in those villi that contain at least 5 capillaries of the sinusoid type.

Placental septa in preterm deliveries often have a poorly developed stroma and can sometimes consist almost of cytotrophoblast elements which is characterized by a significant polychromasia cores. Large areas of the septum surface may be covered with fibrinoid. During the physiological course of pregnancy, fibrinoid plays the role of immune protection and belongs to compensatory and adaptive mechanisms. Out tests revealed the reliable growth of fetal fibrinoid $-6.4 \pm 1.4 \%$ (control value $-4.2 \pm 0.8 \%$ ). The tendency to maternal fibrinoid increase, from our point of view, dis- 
rupts blood circulation in the fetoplacental system. This fact can be confirmed by the interstitial space indicators, which in the main group was $21.2 \pm 1.6 \%$.

Conclusions. A retrospective clinical and statistical analysis of the frequency and course of preterm deliveries over the past five years revealed a number of social, medical and biological factors that contribute to the induction of prematurity and negatively effect on the functional state of the fetus and, accordingly, may have a prognostic character. The main factors for the preterm deliveries development include the young and late reproductive age, low material facility, late antenatal clinic registration, as well as a high percentage of extarental and gynecological pathology in the anamnesis. Analysis of the early neonatal period course in premature newborns revealed a significant percentage of pathological conditions associated primarily with immaturity of organs and systems, unfavorable pregnancy and complications during preterm deliveries.

The adverse effect of the threatening preterm deliveries on the functional state of the intrauterine fetus is especially unfavorable at 28-30 weeks of gestation and is characterized by a decrease in the compensatory and adaptive mechanisms of the fetus.

Placental morphological examination indicated the presence of immune sensitization of the maternal body by fetal alloantigens, which in turn affects the morphofunctional features of the fetoplacental complex. Undoubtedly, the above results make it necessary to introduce a correction method with an impact on the functional state of the fetus, the course of pregnancy and preterm deliveries.

\section{References:}

1. Аналіз смертності та наслідків передчасних пологів: від новонародженої дитини до дорослої людини. Частина 2 серії «Передчасні пологи». 3 турботою про жінку. 2011.3 (24). 26-31.

2. Антипкин Ю.Г., Давыдова Ю.В. Основные направления развития перинатальной медицины. Репродуктив. эндокринология. 2012. 2. $5-7$.

3. Бенюк В.О., Диндар О.А. Цитокіновий профіль і імуногістохімічний стан ендометрію жінок із невиношуванням вагітності на тлі надлишкової маси тіла метаболічного синдрому. Імунологія та алергологія: наука і практика. 2014. 4. 33-37.

4. Венцківська I.В., Страшко I.В., Венцівський К.О., Загородня О.С. Передчасний розрив плодових оболонок: нові генети- 
чні чинники та можливий патогенез їхньої реалізації. Здоровье Женщиныл. 2017. 2 (118). 26-29.

5. Веропотвелян П.Н., Веропотвелян Н.П., Панасенко А.Н., Горук П.С. (2012). Преждевременное излитие околоплодных вод при недоношенной беременности - что делать? Здоровье женщины. 2012. 1 (67). 99-104.

6. Веропотвелян П.Н., Белая В.В., Веропотвелян Н.П. Современные клинические подходы к лечению угрожающих преждевременных родов. Здоровье женщиныл. 2014. 3. 78-83.

7. Іванюта С.О. Передчасні пологи (Клінічна лекція). Неонатологія, хірургія та перинатальна медицина. 2012. II. 1(3). 71-75.

8. Пірогова В.І., Місюра А.Г. Клінічні варіанти перебігу передчасного розриву плодових оболонок. Перинатальні аспекти. Актуальні питання педіатрії, акушерства та гінекології. Тернопіль. 2015. 2. 147-149.

9. Boots C. E. Bernardi L.A., Stephenson M.D. Frequency of euploid miscarriage is increased in obese women with recurrent early pregnancy loss. Fertility and Sterility. 2014. 102 (2). 455-459.

10. Hubinont C., Debieve F. Профілактика передчасних пологів: новини токолізу. Жіночий лікар. 2012. 2: 21-24.

DOI https://doi.org/10.30525/978-9934-588-81-5-1.17

\title{
THROMBOELASTOGRAPHY IS AN EARLY METHOD OF CONTROL OF HEMOSTASIC DISORDERS DURING PREGNANCY WITH ANTENATAL FETAL DEATH
}

\author{
Hinzburh V. H. \\ $M D$,
}

Professor at the Department of Obstetrics and Gynecology № 3

Bogomolets National Medical University

Gychka N. M.

$P h D$,

Associate Professor at the Department of Obstetrics and Gynecology № 3

Bogomolets National Medical University

Chebotaryova A. S.

Assistant at the Department of Obstetrics and Gynecology № 3, Bogomolets National Medical University 